\title{
On soil genesis in temperate humid climate. III. Some other soil groups
}

\section{J. VAN SCHUYLENBORGH}

Department of Regional Pedology, Mineralogy and Geology, Agricultural University, Wageningen, Netherlands

\section{Summary}

Some characteristics of the formation of a Grey-Brown/Red-Yellow Podzolic Intergrade, Rendzina, Grumusol and Grumusolic soil, Braunerde and Brown Forest soil are discussed. It appeared that in the Braunerde silica is the most mobile element, while aluminium is more mobile than iron. The Brown Forest soil and the Grumusolic soil show tendencies, characteristic for podzolization. The Rendzina and Grumusol did not show a distinct change in chemical composition of the horizons, except some removal of silicic acid and alumina during the dissolution of carbonates.

Finally a preliminary and tentative genetical classification was given, using the relative mobilities of $\mathrm{Si}, \mathrm{Al}$ and $\mathrm{Fe}$ and the mobilities of organic matter and the clay fraction as diagnostic criteria.

\section{Introduction}

In part I and II of this series (VAN SchuYlenborgh, 1962, 1963) details had been given about the translocation of a number of soil constituents in Podzols, Podzolic soils, Acid Brown Earths and Gley-soils.

In the present paper some additional remarks will be given about the Grey-Brown Podzolic soils of part I and furthermore details will be reported for a Grey-Brown/ Red-Yellow Podzolic Intergrade, Rendzina, Grumusol, Grumusolic soil, Braunerde and Brown Forest soil.

\section{Methods}

The same procedure was followed as described in part I of this series, however, with two exceptions. Ti was now determined colorimetrically with tiron (SANDELL, 1959): the tiron-concentration was raised to $3 \%$ in order to avoid Al-interference and the Fe-interference was eliminated by chelation with EDTA. Iron was determined colorimetrically with o-phenanthroline.

The cation exchange characteristics were determined according to YAALON, VAN SCHUYLENBORGH and SLAGER (1963). This method was developed for saline soils but could be used for non-saline soils as well. Exchangeable $\mathrm{Al}$ and $\mathrm{H}$ were determined by extraction with $\mathrm{N} \mathrm{KCl}$ (JACKSON, 1958); Al was estimated colorimetrically with aluminon and the $\mathrm{H}$-ions by titration with standard $\mathrm{NaOH}$-solution after complexing $\mathrm{Al}$ with $\mathrm{NaF}$.

Received for publication 10th February, 1964. 
ON SOIL GENESIS IN TEMPERATE HUMID CLIMATE. III. SOME OTHER SOIL GROUPS

\section{Results and discussion}

a. Grey-Brown Podzolic soils

The profiles VI and VII of part I were classified as orthic Typudalfs. This is justified when considering the intensity of weathering and of soil formation, which are of the same order of magnitude. Base saturation and manganese translocation, however, are quite different. Profile VII has in the upper $53 \mathrm{~cm}\left(A_{p}, A_{2}, B_{1}\right)$ a base saturation of $50 \%$ and lower (see TABLE 5), whereas profile VI has only in the $A_{2}$ a base saturation of $50 \%$. Manganese translocation in profile VII shows the same tendency as the iron translocation (see Table 1 in part $I$ of this series), whereas profile VI shows a even distribution of manganese. Both phenomena are probably caused by reduction conditions in the first stage of the formation of profile VI, which is understandable if it is realised that this profile is situated on an old river levee. Whether this difference in the profiles is sufficient to include another sub-group in the Typudalfs is questionable. However, they have to be differentiated on the family level.

\section{b. Grey-Brown/Red-Yellow Podzolic Intergrade} (Ochrultic Typudalf)

Profile XV is an example of the profiles investigated (see APPENDIX: Profile descriptions). The translocation of aluminium and especially of iron, manganese and clay is very pronounced (TABLE 1,2,3 and 4).

The texture varies from loamy sand in the A-horizon to clay loam in the illuvial horizon. Fe- and Mn-contents in the $B_{2}$ amounts to 5-6 times that of $A_{p}$, whereas the $\mathrm{Al}$-content is $3-4$ times as great as that of the $A_{p}$. The considerable accumulation of $\mathrm{Mn}$ and $\mathrm{Fe}$ indicates again that reduction conditions occured during the formation of the soil as a consequence of its position on the low terrace of the Meuse. The profile is strongly weathered: the sand fraction contains $85 \%$ quartz, $5 \%$ orthoclase, $8 \%$ iron-concretions and $2 \%$ heavy minerals, predominantly epidote, zircon and tourmaline.

In contradiction to the highly weathered state of the profile stands the high base saturation (TABLE 5). This may be the result of the intense agricultural use of the soil. The high dressings of fertilizers may have caused a definite increase of the basesaturation, which is also reflected in the decrease of the $\mathrm{pH}$ and increase of exchangeable Al (TABLE 5) of the $A_{p}$ to $B_{1}$-horizon. Anyway, it is evident that we have to do here with an intergrade soil: the 7 th Approximation recognizes such soils in the subgroup of the Ochrultic Typudalfs.

The relative mobilities, as can be derived from the molar ratios (TABLE 3) of $\mathrm{Si}, \mathrm{Al}$ and $\mathrm{Fe}$ are similar to those of the podzolic and Gley-soils; consequently it can be expected that the formation mechanism of true Red-Yellow Podzolic soils will be similar as well.

c. Rendzina, Grumusol, and Braunerde (Prof. XVI, XVII and XVIII respectively)

Although the profiles are not ideal (see APPENDIX: Profile descriptions) as far as the parent material is concerned, which is not homogeneous, some conclusions can be drawn from the analyses (TABLE 1,2 and 3), especially in the case of the Braunerde. The clay fraction of the lower part (II) of this profile is certainly of the same origin, 
TABLE 1. Elemental composition of the soils (expressed in $\%$ of the fine-earth fraction dried at $105^{\circ} \mathrm{C}$ )

\begin{tabular}{|c|c|c|c|c|c|c|c|}
\hline \multirow[t]{2}{*}{ Prof. } & \multirow[t]{2}{*}{ Hor. } & \multirow{2}{*}{$\begin{array}{l}\text { Thickness } \\
\mathrm{cm}\end{array}$} & \multirow{2}{*}{$\begin{array}{l}\mathrm{C} \\
\%\end{array}$} & \multirow{2}{*}{$\begin{array}{l}\mathbf{N} \\
\%\end{array}$} & \multirow[t]{2}{*}{$\mathrm{C} / \mathrm{N}$} & \multicolumn{2}{|c|}{$\mathrm{pH}$} \\
\hline & & & & & & $\mathrm{H}_{2} \mathrm{O}$ & $\underset{\mathrm{CaCl}_{2}}{0,01 \mathrm{~m}}$ \\
\hline$X V$ & $\begin{array}{l}\mathbf{A}_{\mathrm{p}} \\
\mathbf{A}_{2} \\
\mathbf{B}_{1} \\
\mathbf{B}_{2 \mathbf{t}} \\
\text { II } \mathbf{C}\end{array}$ & $\begin{array}{r}0-25 \\
25-38 \\
38-64 \\
64-95 \\
95-100\end{array}$ & $\begin{array}{c}1,16 \\
0,60 \\
0,50 \\
0,40 \\
\text { tr }\end{array}$ & $\begin{array}{c}0,081 \\
0,044 \\
0,068 \\
0,076 \\
\text { tr }\end{array}$ & $\begin{array}{r}14,4 \\
13,7 \\
7,3 \\
5,3 \\
\end{array}$ & $\begin{array}{l}6,24 \\
5,05 \\
4,82 \\
5,56 \\
6,26\end{array}$ & $\begin{array}{l}5,64 \\
4,50 \\
4,10 \\
5,16 \\
5,74\end{array}$ \\
\hline XVI & $\begin{array}{l}\mathrm{A}_{\mathrm{p}} \\
\text { II B } \\
\text { II C }\end{array}$ & $\begin{array}{r}0-16 \\
16-26 \\
26-39\end{array}$ & $\begin{array}{c}1,80 \\
0,51 \\
\text { tr }\end{array}$ & $\begin{array}{l}\text { n.d. } \\
\text { n.d. } \\
\text { n.d. }\end{array}$ & $\bar{z}$ & $\begin{array}{l}7,61 \\
7,72 \\
8,00\end{array}$ & $\begin{array}{l}7,34 \\
7,41 \\
7,50\end{array}$ \\
\hline XVII & $\begin{array}{l}\mathrm{A}_{\mathrm{P}} \\
\text { II } \mathrm{B}_{1} \\
\text { II } \mathrm{B}_{2} \\
\text { II C } \\
\text { II R }\end{array}$ & $\begin{array}{c}0-10 \\
10-19 \\
19-48 \\
48-54 \\
+54\end{array}$ & $\begin{array}{l}2,01 \\
0,46 \\
0,45 \\
0,47 \\
\text { n.d. }\end{array}$ & $\begin{array}{r}0,255 \\
0,096 \\
0,101 \\
0,091 \\
\text { n.d. }\end{array}$ & $\begin{array}{l}7,9 \\
4,8 \\
4,5 \\
5,1 \\
-\end{array}$ & $\begin{array}{l}7,38 \\
7,61 \\
7,68 \\
8,08 \\
\text { n.d. }\end{array}$ & $\begin{array}{l}7,06 \\
7,28 \\
7,22 \\
7,70 \\
\text { n.d. }\end{array}$ \\
\hline XVIII & $\begin{array}{l}\mathbf{A}_{1} \\
\mathbf{A}_{3} \\
\text { II } \mathbf{B}_{1} \\
\text { II } \mathbf{B}_{2} \\
\text { II } \mathbf{B}_{3} \\
\text { II } \mathbf{C}\end{array}$ & $\begin{array}{r}0-29 \\
29-59 \\
59-90 \\
90-120 \\
120-130 \\
+130\end{array}$ & $\begin{array}{l}2,30 \\
0,76 \\
0,34 \\
0,33 \\
0,29 \\
\text { n.d. }\end{array}$ & $\begin{array}{c}0,254 \\
0,092 \\
0,061 \\
0,042 \\
0,017 \\
\text { n.d. }\end{array}$ & $\begin{array}{r}9,1 \\
8,3 \\
5,6 \\
7,8 \\
17,1 \\
-\end{array}$ & $\begin{array}{l}7,70 \\
7,80 \\
7,58 \\
7,89 \\
8,02 \\
8,01\end{array}$ & $\begin{array}{l}7,36 \\
7,37 \\
7,21 \\
7,20 \\
7,64 \\
7,50\end{array}$ \\
\hline $\mathrm{XIX}$ & $\begin{array}{l}\mathbf{A}_{1} \\
\mathbf{B}_{1} \\
\mathbf{B}_{2} \\
\mathbf{B}_{3}(\mathbf{C})\end{array}$ & $\begin{array}{r}0-8 \\
8-25 \\
25-50 \\
50-85\end{array}$ & $\begin{array}{l}2,14 \\
0,65 \\
0,38 \\
0,24\end{array}$ & $\begin{array}{l}\text { n.d. } \\
\text { n.d. } \\
\text { n.d. } \\
\text { n.d. }\end{array}$ & $\begin{array}{l}- \\
-\end{array}$ & $\begin{array}{l}7,45 \\
7,96 \\
7,85 \\
8,16\end{array}$ & $\begin{array}{l}7,11 \\
7,43 \\
7,36 \\
7,64\end{array}$ \\
\hline $\mathbf{X X}$ & $\begin{array}{l}\mathbf{A}_{1} \\
\mathbf{A}_{\mathbf{3}} \\
\mathbf{B}_{1} \\
\mathbf{B}_{2} \\
\mathbf{C}\end{array}$ & $\begin{array}{r}0-22 \\
22-70 \\
70-80 \\
80-95 \\
+95\end{array}$ & $\begin{array}{l}1,72 \\
0,76 \\
0,49 \\
0,46 \\
0,36\end{array}$ & $\begin{array}{l}0,121 \\
0,077 \\
0,049 \\
0,051 \\
0,044\end{array}$ & $\begin{array}{r}14,2 \\
9,9 \\
10,0 \\
9,0 \\
8,2\end{array}$ & $\begin{array}{l}7,55 \\
7,78 \\
7,77 \\
7,86 \\
7,85\end{array}$ & $\begin{array}{l}7,36 \\
7,37 \\
7,36 \\
7,32 \\
7,36\end{array}$ \\
\hline
\end{tabular}

and alterations in its composition can therefore be regarded as a result of soil formation.

It is evident that the translocation of $\mathrm{Si}, \mathrm{Al}$ and $\mathrm{Fe}$ is quite different as compared with podzolic soils. Here, the silica is the mobile part, whereas $\mathrm{Al}$ and $\mathrm{Fe}$ are enriched in the surface layers or remain more or less constant. Furthermore $\mathrm{Al}$ is more mobile than iron, as in Acid Brown Earth. This can be explained either by assuming that humus does not play a rôle in the formation of these soils, so that soil formation is more or less a weathering process, or by assuming that the humates have quite different properties than those of podzolic soils.

In the first case the high mobility of $\mathrm{Si}$ can be explained by the alkalinity, so that soluble silicates can be formed which are leached down. The iron and aluminium accumulate as hydroxides. Because Al-hydroxide is more soluble than Fe-hydroxide, aluminium tends to be more mobile than iron. In the second case we have to assume that the humus acids with $\mathrm{Al}$ form a more stable complex than iron, or that the 
ON SOIL GENESIS IN TEMPERATE HUMID CLIMATE, III. SOME OTHER SOIL GROUPS

\begin{tabular}{|c|c|c|c|c|c|c|c|c|}
\hline$\underset{\%}{\mathrm{SiO}_{2}}$ & $\underset{\%}{\mathrm{Al}_{2} \mathrm{O}_{3}}$ & $\underset{\%}{\mathrm{Fe}_{2} \mathrm{O}_{3}}$ & $\begin{array}{c}\mathrm{CaO} \\
\%\end{array}$ & $\underset{\%}{\mathrm{MgO}}$ & $\underset{\%}{\mathrm{TiO}_{2}}$ & $\underset{\%}{\mathrm{MnO}}$ & $\begin{array}{c}\text { Free iron } \\
\%\end{array}$ & $\begin{array}{c}\mathrm{CaCO}_{3} \\
\%\end{array}$ \\
\hline 87,2 & 2,74 & 1,92 & n.d. & n.d. & 0,27 & 0,055 & 1,06 & - \\
\hline 87,9 & 3,08 & 1,97 & n.d. & n.d. & 0,29 & 0,064 & 1,34 & - \\
\hline 82,2 & 6,22 & 4,92 & n.d. & n.d. & 0,51 & 0,172 & 3,60 & - \\
\hline 72,8 & 9,78 & 10,2 & n.d. & n.d. & 0,70 & 0,241 & 8,03 & - \\
\hline 92,1 & 2,38 & 1,98 & n.d. & n.d. & 0,19 & 0,030 & 1,27 & - \\
\hline 63,5 & 12,2 & 5,76 & 3,72 & 1,16 & 0,64 & 0,073 & n.d. & 3,70 \\
\hline 54,5 & 17,5 & 8,08 & 2,35 & 1,73 & 0,77 & 0,086 & n.d. & 1,36 \\
\hline 8,57 & 1,67 & 1,44 & 48,7 & 0,09 & 0,12 & 0,013 & n.d. & 88,6 \\
\hline 66,8 & 10,8 & 7,84 & 1,78 & 0,61 & 0,73 & 0,126 & n.d. & 0,18 \\
\hline 56,7 & 18,4 & 10,3 & 1,43 & 1,43 & 0,78 & 0,069 & n.d. & 0,16 \\
\hline 59,5 & 16,7 & 8,89 & 1,51 & 1,43 & 0,76 & 0,081 & n.d. & 0,24 \\
\hline 44,5 & 14,3 & 7,84 & 13,3 & 2,20 & 0,57 & 0,060 & n.d. & 21,2 \\
\hline 3,19 & 0,72 & 0,18 & 52,1 & 0,18 & 0,05 & 0,009 & n.d. & 94,5 \\
\hline 80,5 & 5,76 & 3,17 & 1,50 & 0,47 & 0,50 & 0,208 & n.d. & 1,28 \\
\hline 81,2 & 6,58 & 3,73 & 0,87 & 0,51 & 0,59 & 0,194 & n.d. & 0,48 \\
\hline 81,4 & 7,31 & 4,12 & 0,67 & 0,47 & 0,70 & 0,170 & n.d. & 0,10 \\
\hline 80,9 & 8,05 & 4,06 & 0,77 & 0,63 & 0,77 & 0,112 & n.d. & tr \\
\hline 70,3 & 7,57 & 3,18 & 7,15 & 0,88 & 0,78 & 0,074 & n.d. & 12,3 \\
\hline 12,3 & 1,37 & 0,63 & 45,4 & 2,46 & 0,12 & 0,030 & n.d. & 81,5 \\
\hline 57,0 & 12,8 & 4,99 & 1,21 & 5,20 & 0,77 & 0,138 & n.d. & $\mathrm{tr}$ \\
\hline 57,8 & 13,9 & 5,18 & 1,67 & 5,83 & 0,87 & 0,093 & n.d. & 2,10 \\
\hline 57,3 & 14,8 & 5,55 & 1,20 & 6,49 & 0,85 & 0,107 & n.d. & 3,10 \\
\hline 37,1 & 8,99 & 4,74 & 15,3 & 6,34 & 0,58 & 0,107 & n.d. & 22,2 \\
\hline 67,2 & 12,2 & 3,07 & 2,22 & 0,88 & 0,38 & 0,098 & 1,33 & 3,11 \\
\hline 68,0 & 12,5 & 3,22 & 2,09 & 0,93 & 0,38 & 0,100 & 1,39 & 2,40 \\
\hline 69,2 & 13,2 & 3,66 & 0,99 & 0,88 & 0,42 & 0,106 & 1,95 & 0,37 \\
\hline 67,7 & 13,7 & 4,57 & 0,82 & 1,01 & 0,48 & 0,110 & 2,56 & 0,29 \\
\hline 67,8 & 13,9 & 4,62 & 1,12 & 1,15 & 0,51 & 0,099 & 1,93 & 0,20 \\
\hline
\end{tabular}

Fe-complex is more liable to hydrolysis than the Al-complex. However that may be, a conclusive answer or another explanation is only possible when more is known about the chemical properties of humus acids.

The Rendzina and Grumusol do not show clear chemical horizon differentiation which, in fact, cannot be expected. The analyses only show that during the dissolution of the carbonates, some silicic acid and alumina has been removed, whereas iron oxide has been accumulated.

The classification of the Rendzina and the Braunerde in terms of the 7th Approximation meets no difficulties; the respective names are Hapludollic Rendoll and Orthic Hapludoll. The classification of the Grumusol is more difficult. If the upper foreign $10 \mathrm{~cm}$ are disregarded, the soil belongs to the order of the Vertisols, suborder of the Usterts and great group of the Mazusterts. The colour of the soil does not meet the requirements of an Orthic Mazustert; moreover, the clay composition and exchange capacity indicate that the clay is not purely montmorillonitic, which reflects the 
Table 2. Partial elemental composition of the clay separates

\begin{tabular}{|c|c|c|c|c|c|c|}
\hline Prof. & Hor. & $\underset{\%}{\mathrm{SiO}_{2}}$ & $\underset{\%}{\mathrm{Al}_{2} \mathrm{O}_{3}}$ & $\underset{\%}{\mathrm{Fe}_{2} \mathrm{O}_{3}}$ & $\underset{\%}{\mathrm{TiO}_{2}}$ & $\underset{\%}{\mathrm{MnO}}$ \\
\hline$X V$ & $\begin{array}{l}\mathbf{A}_{\mathrm{p}} \\
\mathbf{A}_{2} \\
\mathbf{B}_{1} \\
\mathbf{B}_{2 t} \\
\text { II } \mathbf{C}\end{array}$ & $\begin{array}{l}46,9 \\
43,1 \\
38,6 \\
33,8 \\
38,3\end{array}$ & $\begin{array}{l}21,3 \\
23,0 \\
22,0 \\
19,3 \\
19,6\end{array}$ & $\begin{array}{l}14,8 \\
16,5 \\
21,4 \\
24,9 \\
21,4\end{array}$ & $\begin{array}{l}1,16 \\
1,11 \\
1,07 \\
0,94 \\
0,87\end{array}$ & $\begin{array}{l}0,066 \\
0,081 \\
0,105 \\
0,138 \\
0,104\end{array}$ \\
\hline XVI & $\begin{array}{l}\mathrm{A}_{\mathrm{p}} \\
\text { II } \mathrm{B} \\
\text { II C }\end{array}$ & $\begin{array}{l}42,1 \\
39,7 \\
40,3\end{array}$ & $\begin{array}{l}20,8 \\
19,1 \\
15,5\end{array}$ & $\begin{array}{c}10,9 \\
9,92 \\
5,52\end{array}$ & $\begin{array}{l}0,81 \\
0,71 \\
0,68\end{array}$ & $\begin{array}{l}\text { n.d. } \\
\text { n.d. } \\
\text { n.d. }\end{array}$ \\
\hline XVII & $\begin{array}{l}A_{p} \\
\text { II } B_{1} \\
\text { II } B_{2} \\
\text { II C } \\
\text { II R }\end{array}$ & $\begin{array}{l}37,9 \\
38,2 \\
41,7 \\
40,4 \\
39,0\end{array}$ & $\begin{array}{l}20,0 \\
15,5 \\
20,5 \\
18,5 \\
15,2\end{array}$ & $\begin{array}{c}13,8 \\
11,1 \\
11,4 \\
11,4 \\
4,94\end{array}$ & $\begin{array}{l}0,69 \\
0,61 \\
0,72 \\
0,65 \\
0,68\end{array}$ & $\begin{array}{l}\text { n.d. } \\
\text { n.d. } \\
\text { n.d. } \\
\text { n.d. } \\
\text { n.d. }\end{array}$ \\
\hline XVIII & $\begin{array}{l}\mathbf{A}_{1} \\
\mathbf{A}_{3} \\
\text { II } \mathbf{B}_{1} \\
\text { II } \mathbf{B}_{2} \\
\text { II } \mathbf{B}_{3} \\
\text { II } \mathbf{C}\end{array}$ & $\begin{array}{l}36,8 \\
29,5 \\
33,1 \\
34,5 \\
36,2 \\
29,5\end{array}$ & $\begin{array}{l}18,3 \\
16,8 \\
17,8 \\
16,9 \\
16,7 \\
12,5\end{array}$ & $\begin{array}{c}14,8 \\
14,4 \\
15,1 \\
13,1 \\
10,9 \\
7,02\end{array}$ & $\begin{array}{l}0,95 \\
0,80 \\
0,80 \\
0,79 \\
0,85 \\
0,72\end{array}$ & $\begin{array}{l}0,075 \\
0,077 \\
0,072 \\
0,061 \\
0,050 \\
0,029\end{array}$ \\
\hline XIX & $\begin{array}{l}\mathbf{A}_{1} \\
\mathbf{B}_{1} \\
\mathbf{B}_{2} \\
\mathbf{B}_{3}(\mathbf{C})\end{array}$ & $\begin{array}{l}44,7 \\
43,6 \\
42,7 \\
43,2\end{array}$ & $\begin{array}{l}19,9 \\
19,8 \\
19,8 \\
19,1\end{array}$ & $\begin{array}{l}7,67 \\
7,76 \\
7,69 \\
7,83\end{array}$ & $\begin{array}{l}0,87 \\
0,83 \\
0,80 \\
0,74\end{array}$ & $\begin{array}{l}0,038 \\
0,042 \\
0,040 \\
0,049\end{array}$ \\
\hline$x x$ & $\begin{array}{l}\mathbf{A}_{1} \\
\mathbf{A}_{3} \\
\mathbf{B}_{1} \\
\mathbf{B}_{2} \\
\mathbf{C}\end{array}$ & $\begin{array}{l}37,4 \\
37,5 \\
36,4 \\
36,3 \\
36,7\end{array}$ & $\begin{array}{l}24,2 \\
24,5 \\
24,9 \\
25,7 \\
25,0\end{array}$ & $\begin{array}{l}11,2 \\
11,7 \\
13,7 \\
15,4 \\
15,8\end{array}$ & $\begin{array}{l}1,24 \\
1,21 \\
1,17 \\
1,16 \\
1,16\end{array}$ & $\begin{array}{l}0,118 \\
0,116 \\
0,131 \\
0,121 \\
0,125\end{array}$ \\
\hline
\end{tabular}

fact that the cracks are not as wide as could be expected in such a heavy soil. Therefore it is proposed to introduce a fourth subgroup, viz. Entic Mazustert.

\section{d. Grumusolic soil (Vertic Eutochrept, Prof. XIX)}

This soil was reckognized and mapped by VerHoEVEN (1963) in Luxemburg and analyzed in the author's laboratory. The soil has been formed on Steinmergelkeuper. The weathering product of this material is the Steinmergelkeuper-clay, that contains about $70 \%$ illite and $30 \%$ chlorite (JUNGERIUs, 1959). These minerals are known to be transformed under certain conditions into forms with expanding lattices (ScHEFFER and Schachtschabel, 1960). It is therefore, that this soil shows grumusolic characteristics (see APPENDIX: Profile descriptions).

The clay content is lower than in the Grumusol, discussed above, and this is possibly the reason that in the formation of this soil already weak podzolic tendensies can be observed. The silica is already somewhat less mobile than $\mathrm{Fe}$ and $\mathrm{Al}$, while iron is more mobile than aluminium. There is also a weak clay migration, although too small to give rise to an argillic horizon. 
ON SOIL GENESIS IN TEMPERATE HUMID CLIMATE. III. SOME OTHER SOIL GROUPS

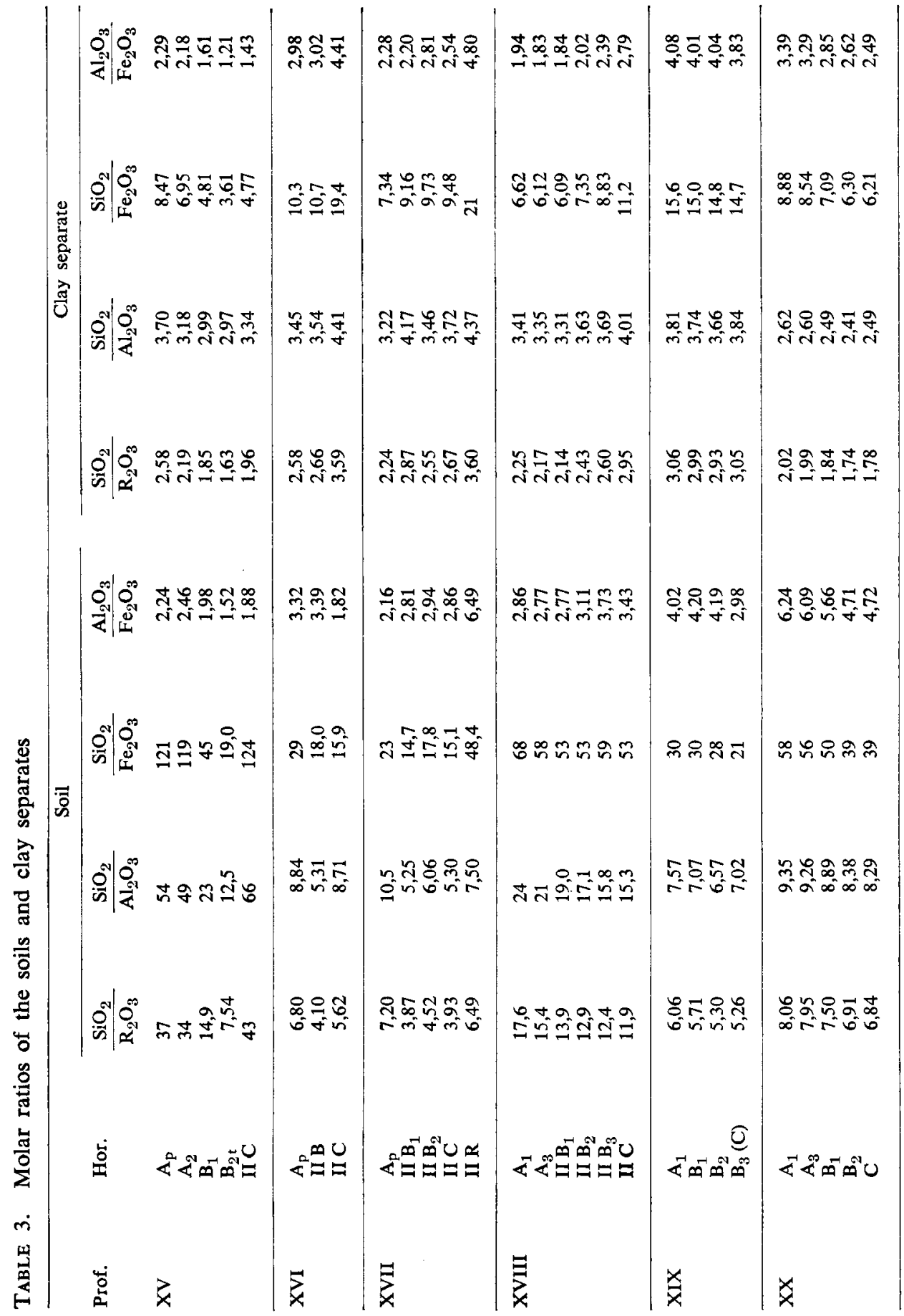

Neth. J. agric. Sci., Vol. 12 (1964) No. 3 (August) 
J. VAN SCHUYLENBORGH

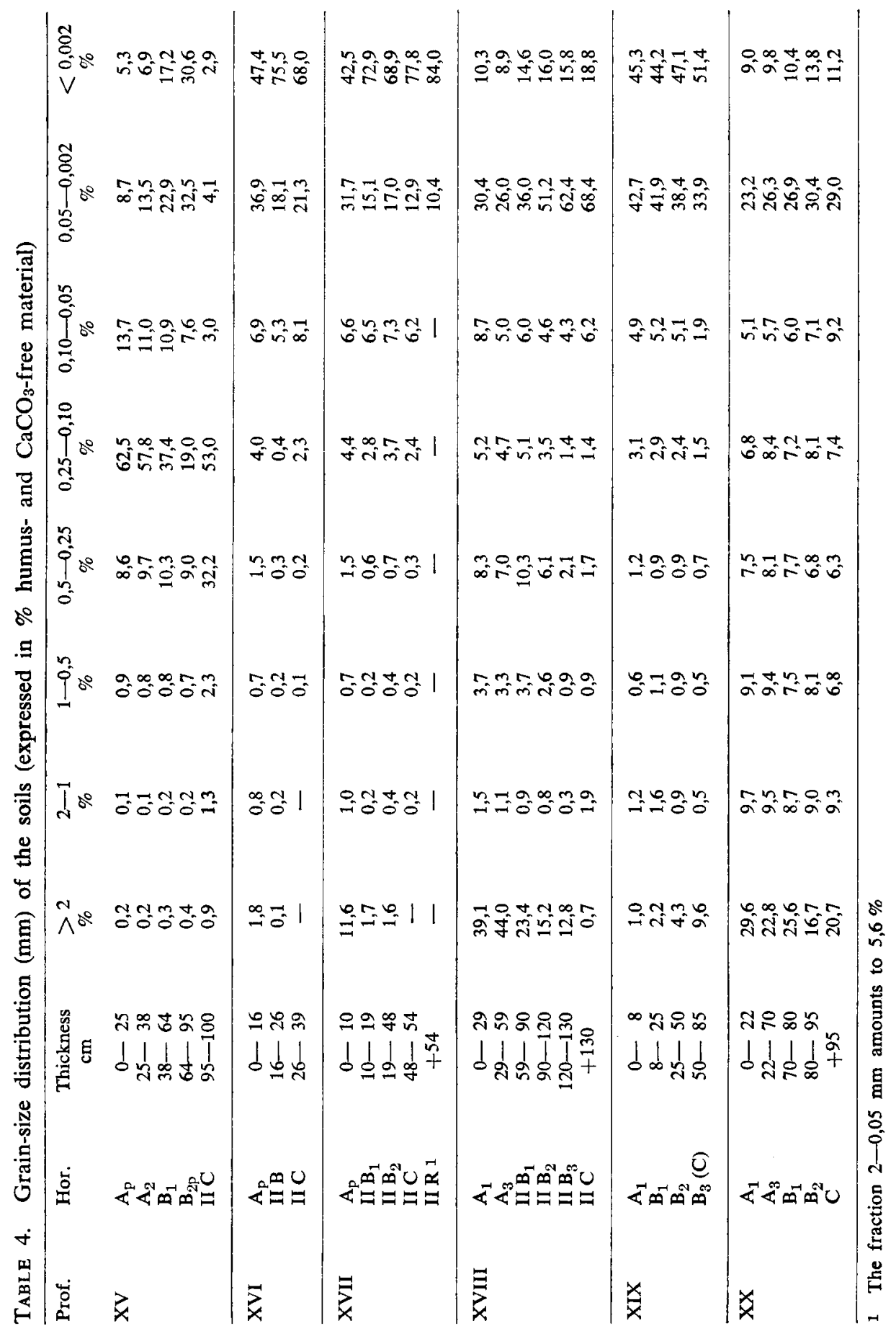


ON SOIL GENESIS IN TEMPERATE HUMID CLIMATE. III. SOME OTHER SOIL GROUPS

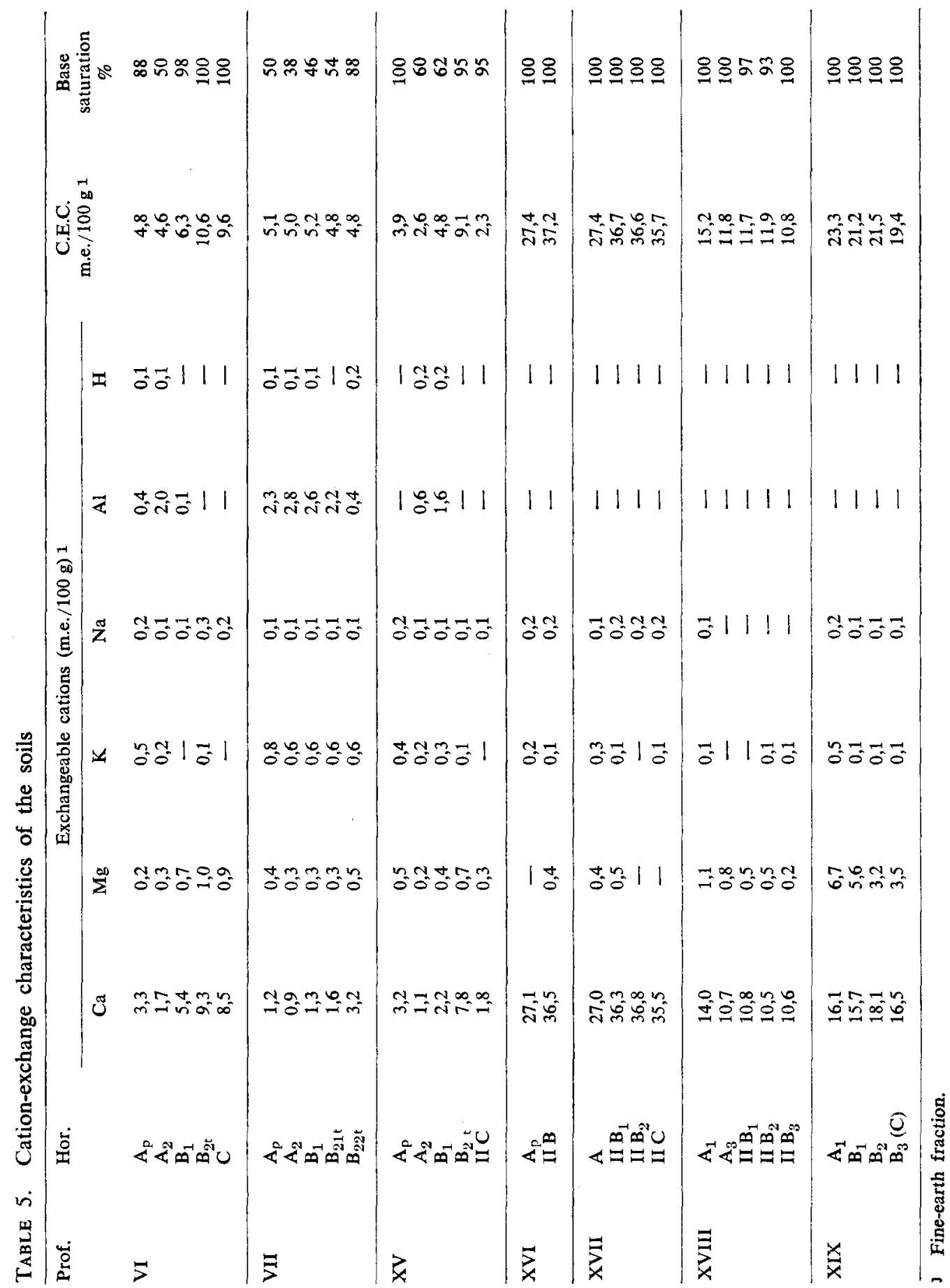

Neth. J. agric. Sci., Vol. 12 (1964) No. 3 (August) 
The coatings observed in the profile (see APPENDIX) are predominantly pressure coatings. It can be concluded that, although the translocations of the soil constituents are too small for the recognition of horizons other than an ochric epidedon and cambic horizon, the soil starts to form a podzolic soil, or is a stationary transitional case between an Inceptisol and Alfisol.

\section{e. Brown Forest Soil (Orthic Eutochrept or Orthic Cryochrept, Prof. XX)}

This profile is a still more advanced step in the podzolization process, probably as a consequence of the lower clay content. TABLE 4 shows that the clay content in the $\mathbf{B}_{2}$-horizon is so much higher than in the A-horizon, that the $\mathbf{B}_{2}$ could be an argillic horizon. However, the clay skins are so minimal and discontinuous, that the higher clay content has to be considered mostly as a formation in situ. The B2-horizon is therefore a cambic horizon. Furthermore, there is a certain removal of $\mathrm{Al}$ and $\mathrm{Fe}$ from the solum, with the subsequent enrichment of silica in the surface layers (TABLE 3); here too, $\mathrm{Fe}$ is more mobile than Al (Analyses of similar soils can be found in RoBinson, 1949). This profile, as the preceding one, seems to be transitional stage between an Inceptisol and Alfisol. Both profiles prove, that weak podzolization can also occur under neutral to weakly alkaline conditions.

\section{f. $\mathrm{Ca}$ a n d $\mathrm{Mg}$}

Considering the soils under forest vegetations (prof. XVIII and XX), it follows from TABLE 1 and from the base saturation (TABLE 5), that $\mathrm{Ca}$ first decreases with depth and than increases, whereas the $\mathrm{Mg}$-content increases gradually with depth. The horizon with the lowest $\mathrm{Ca}$-content coincides with the horizon where the last roots could be observed. This phenomenon has been frequently found by other authors and was also observed under humid tropical conditions by the author. Apparently, there are two processes that control this phenomenon, viz. the absorption of nutritional cations by the roots, transportations into leaves followed by a return to the soil after dying of the leaves and the washing out by rains. It depends on the relative intensities of these two processes, whether a nutritional element is accumulated in the surface layers or washed down.

\section{Conclusions}

The results, reported in the three papers, seem to permit the recognition of a number of classes of soil-formation processes, although it has to be emphasized that this classification is very tentative and may be changed or extended after further investigations.

The relative mobilities of silicium, aluminium and iron were used as diagnostic criteria for 4 classes; furthermore, the illuviation of organic matter and clay as criteria for the sub-division of the sub-classes. In this way the following scheme was established.

$$
\text { Class } I \quad m_{F_{e}}>m_{A l}>m_{\mathrm{Si}} \quad \text { (m designates mobility). }
$$

I.1 accumulation of organic matter at some depth.

I.2 accumulation of clay at some depth.

I.3 constancy or decrease of clay with depth. 
C1 as s II $\quad \mathbf{m}_{\mathrm{Al}}>\mathrm{m}_{\mathrm{Si}}>\mathrm{m}_{\mathrm{Fe}}$

II.1 accumulation of clay at some depth.

II. 2 constancy or decrease of clay content with depth.

Class III $\mathrm{m}_{\mathrm{Si}} \geqslant \mathrm{m}_{\mathrm{Al}} \geqslant \mathrm{m}_{\mathrm{Fc}}$

III.1 accumulation of clay at some depth.

III. 2 constancy or decrease of clay with depth.

Clas s IV Miscellaneous. It is possible that during soil formation a change in climate or a lowering of the ground-water level has taken place. This can lead to an irregular distribution of the weathering products in the solum.

Examples of 1.1 are the Spodosols (Prof. $\mathrm{I}$ to $\mathrm{V}$, and $\mathrm{X}$ in part $\mathrm{I}$ of this series). Examples of $I .2$ are the Udalfs (Prof. VI and VII in part $I$ and $X V$ in this part of the series), the Aquult and Aqualfs (Prof. XII, XI and XIV, respectively, in part I). Examples of $\mathrm{I} .3$ are the Aquept (Prof. XIII in part I) and the Ochrepts (Prof. XIX and $\mathrm{XX}$ ) of this part of the series. Examples of II.1 are not yet known to the authors in areas with temperate humid climates; examples of II.2 are the Ochrepts (Prof. VIII and IX in part I). Examples of III.2 are the Rendoll, Ustert and Udoll (Prof. XVI, XVII and XVIII) of this part of the series. Examples of III.1 are only known to the author to occur in humid tropical climates (examples are the Grey-Brown and Red-Yellow Podzolic soils, developed under humid tropical conditions (VAN SCHUYLeNBORGH, 1957, 1958).

\section{ACKNOWLEDGEMENTS}

This study was made possible by a grant of the Netherlands Organization for the Advancement of Pure Research (Z.W.O.).

The author wishes to thank Mrs. L. Th. Begheyn and P. HeEres for doing most of the analyses.

JACKSON, M. L. JUNGERIUS, P. D.

Robinson, G. W.

Rummelen, F. F. F. E. van

Sandell, E. B.

SCHEFFER, F., and P. SCHACHTSCHABEL SCHUYLENBORGH, J. VAN

\section{I T E R A T U R E}

1958 Soil Chemical Analysis. New Yersey, U.S.A.

1959 Zur Verwitterung, Bodenbildung und Morphologie der KeuperLiaslandschaft bei Montfort in Luxemburg. Thèse, Luxembourg.

1949 Soils. Their origin, constitution and classification. 3rd Edition, London. $321-322$.

1956 The mineralogical importance if "organic $\mathrm{SiO}_{2}$ " in the soil. Landbouw. 25, 225-230.

1959 Colorimetric determination of traces of metals. New YorkLondon.

1960 Lehrbuch der Agrikulturchemie und Bodenkunde. I. Teil. Bodenkunde. 5th Edition. Stuttgart. 48-49.

1957 Investigations on the classification and genesis of soils, derived from acid tuffs under humid tropical conditions. Neth. J. agric. Sci. 5, 195-211.

1958 On the genesis and classification of soils, derived from andesitic tuffs under humid tropical conditions. Neth. J. agric. Sci. 6, 99-124. 
SCHUYLENBORGH, J. VAN

Smithson, F.

Verhoeven, H. J. M.

YAALON, D. H., J. VAN SCHUYLENBORGH and S. SLAGER
1962 On soil genesis in temperate humid climate. I. Some soil groups in the Netherlands. Neth. J. agric. Sci. 10, 127-147.

1963. On soil genesis in temperate humid climate. II. The behaviour of the non-clay fraction in soil groups. Neth. J. agric. Sci. 11, $10-12$.

1956 Silica particles in some British soils. J. Soil Sci. 7, 122-130.

1958 Grass opal in British soils. J. Soil Sci. 9, 148-155.

1963 Semi-detailed soil survey of a region between Ettelbrück-Merch (Grand-Duchy of Luxemburg). Master's thesis Int. Training Centre of Aerial Survey, Delft.

1962 The determination of cation-exchange characteristics of saline and calcareous soils. Neth. J. agric. Sci. 10, 217-222. 
Photographs 1 and 2 

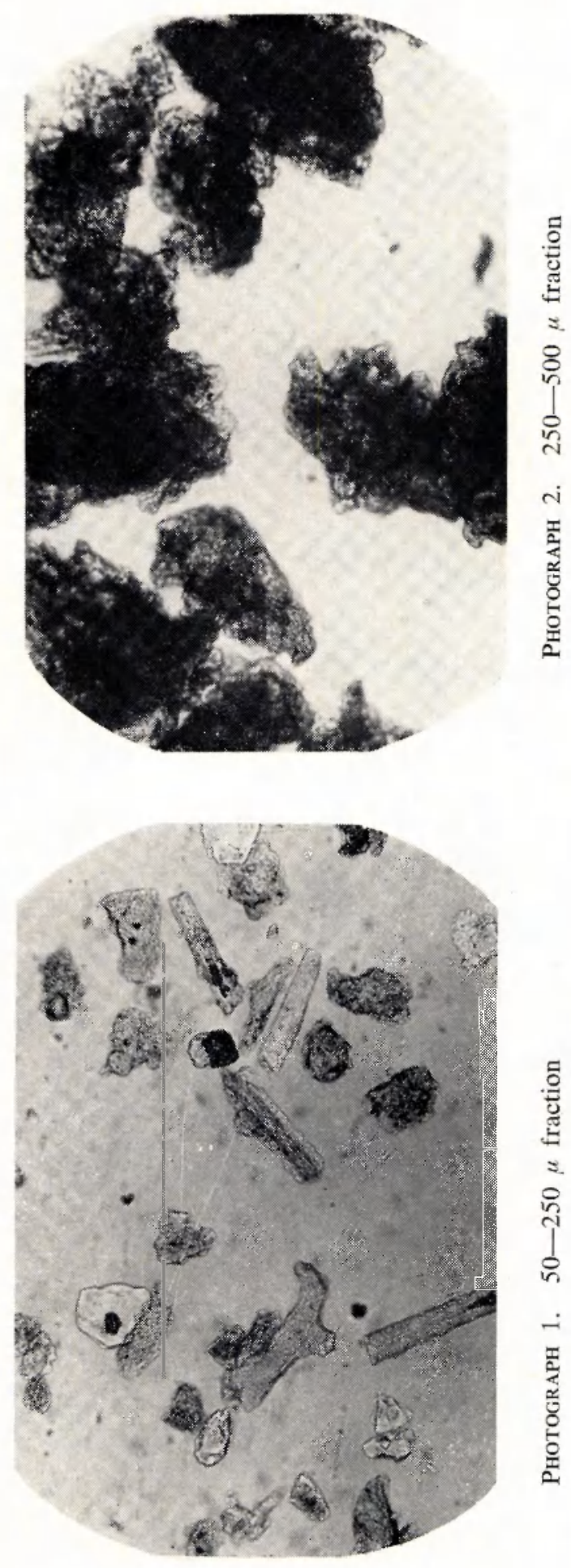


\section{APPENDIX: Profile descriptions}

Prof. XV. Kessel (Limburg). Altitude $20 \mathrm{~m}$. Slightly undulating land. Well-drained. Parent material: river loam. Highest part of the low terrace of the river Meuse. 1 Mean annual rainfall $600 \mathrm{~mm}$. Mean annual temperature $10^{\circ} \mathrm{C}$. Vegetation: cultivated land.

A p 0- $25 \mathrm{~cm}$ Brown (10YR 5/3: dry) to dark grey-brown (10YR 3/3: moist) loamy sand with a weakly developed, crumb structure. Very friable. Many fine roots. Moderate amount of worm casts. Abrupt and smooth on

$\mathrm{A}_{2} \quad 25-38 \mathrm{~cm}$ Light brown (7.5YR 51/2/4: dry) to reddish-brown (5YR 4/4: moist) loamy sand with a weakly developed, thin-platy structure. Friable. Moderate number of fine roots. Some worm tracks, partly filled with material of the $A_{p}$. Diffuse and smooth on

$\mathrm{B}_{1} \quad 38-64 \mathrm{~cm} \quad$ Yellowish-red (5YR 5/6: dry) to reddish-brown (5YR 3\%/4 : moist) sandy loam with a compound, moderate, fine-prismatic and moderate, fine-blocky structure. Many pores present. Slightly sticky. Continuous thin clay skins. Few very fine roots. Few worm tracks. Abrupt and smooth on

$B_{2_{t}} \quad 64-95 \mathrm{~cm}$ Yellowish-red (5YR 4/6: dry and moist) clay loam with moderate, mediumprismatic structure. Many pores present. Sticky. Well-developed continuous clay skins. Very few, very fine roots. No worm tracks. Clear and smooth on

II C 95-100 cm Reddish-yellow (5YR 6/8: dry) to yellowish-red (5YR 5/6: moist) sand. Massive and rather firm. Abrupt and smooth on

III C $+100 \mathrm{~cm}$ Reddish-yellow (7.5YR 7/6: dry) to intense brown (7.5YR 5/7: moist) sand. Very loose.

Prof. XVI. Fromberg (Limburg). Altitude $150 \mathrm{~m}$. High, slightly convex plateau in hilly area. Relief : shallow depression. Well-drained. Parent material: limestone (Upper Senon). Mean annual rainfall $750-800 \mathrm{~mm}$. Mean annual temperature $11^{\circ} \mathrm{C}$. On top of the solum a thin solifluction cover of loessial material and material from the weathered limestone occurs.

A p 0-16 cm Brown (10YR 5/3: dry) to very dark grey-brown (10YR 3/2: moist) clay with a strong, coarse-nutty structure. Friable when moist, hard when dry. Abrupt and wavy on

II B 16- $26 \mathrm{~cm}$ Light yellowish-brown (10YR 6/4: dry) to brown (7.5YR 4/4: moist) clay with a strong, fine-blocky structure. Plastic and sticky. Hard when dry. Clear and wavy on

II C 26- $39 \mathrm{~cm}$ Very pale brown (10YR 8/3: dry-10YR 8/4: moist) somewhat weathered limestone with some root tracks.

II $\mathbf{R}+39 \mathrm{~cm}$ White (10YR 8/1) limestone.

The sand fraction of this soil consists for a consideral part of phytoliths and/or sponge spicules and/or root opal (VAN RUMMELEN, 1953; SMITHSON, 1956, 1958). It appeared that the phytolyths and/or sponge spicules occurred predominantly in the fraction $50-250 \mu$, whereas irregularly formed particles were found in the fraction 250-500 $\mu$ (PHOTOGRAPHS 1 and 2); these latter particles are thought to be formed by root activity. The percentages are respectively for the $A_{p}: 4$ and 25, the II B : 4 and 29; and for the II C: 12 and 65 . X-ray analysis showed that the silica was crystalline. We can conclude from this that the soil is very old and residual.

Prof. XVII. Fromberg (Limburg). The same area as prof. XVI. Same parent material and climate. Higher part of the plateau. Here also a thin solifluction cover of loessial and material from the weathered limestone can be found. Arable land.

A $0-10 \mathrm{~cm}$ Brown (10YR 4/3: dry) to dark brown (10YR 3/3: moist) cherty clay with a strong, coarse-crumb structure. Friable. Abundance of roots. Some worm activity. Clear and smooth on

1 Personal information by Mr. J. M. M. van den Broek. 
II $B_{1} 10-19 \mathrm{~cm}$ Strong brown (7.5YR 5/6: dry and moist) clay with a thin-platy structure. Vertical cracks $1 \mathrm{~cm}$ wide. Plastic and firm. Moderately rooted and some thick horizontal roots. Some worm tracks. Abrupt and smooth on

II $B_{2} 19-48 \mathrm{~cm}$ Strong brown (7.5YR 51/2/6: dry) to brown (7.5YR 5/5: moist) clay with a compound, well-developed, coarse-prismatic and medium-blocky structure. Many pores. Plastic and sticky. Continuous coatings occur. Some slickensides. Worm tracks and cracks filled with dark brown material from the surface. Some fossils of the limestone. Abrupt and wavy on

II C 48- $54 \mathrm{~cm}$ Very pale brown (10YR 7/4: dry) to yellow (10YR 7/6: moist) calcareous clay with a well-developed, blocky structure. The porosity is greater than in the II $B_{2}$. Some roots present. Clear and irregular on

II $R+54 \mathrm{~cm}$ White $(10 \mathrm{YR} 8 / 1)$ limestone. Very porous.

In this profile also phytoliths and/or sponge spicules and/or root opal occur, even to a higher percentage than in prof. XVI. The percentages are respectively for the $A: 6$ and 21 ; for the II $B_{1}$ : 19 and 76 ; the $I I B_{2}$ : 15 and 80 ; and for the II $C: 15$ and 94 . The silica is also crystalline.

Prof. XVIII. Biebos near Valkenburg (Limburg). Altitude $145 \mathrm{~m}$. Hilly area. Rather steep slope. Well-drained. Parent material: an intimate mixture of high-terrace and loessial material, and material derived from the weathered limestone. The upper part of the solum is more gravelly than the lower part. Mean annual rainfall $750-800 \mathrm{~mm}$. Mean annual temperature $11^{\circ} \mathrm{C}$. Vegetation: a dense population of oak, hazel, Acacia and ivy.

A $10-29 \mathrm{~cm}$ Brown (10YR 41/2/3: dry) to dark brown (10YR 3/3: moist) gravelly, sandy loam with a well-developed, medium-crumb structure. Very friable. Intensively rooted. Very porous. Diffuse and smooth on

A3 29- $59 \mathrm{~cm}$ Yellowish-brown (10YR 4/0: dry) to dark yellowish-brown (10YR 5/4: moist) gravelly, sandy loam. Moderately developed, fine-crumb and subangular-blocky structure. Friable. Intensively rooted. Very porous. Gradual and smooth on

II $B_{1} 59-90 \mathrm{~cm}$ Yellowish-brown (10YR 5/6: dry) to brown (7.5YR 4/4: moist) gravelly loam with a moderately developed, fine subangular-blocky structure. Friable. Many roots. Very porous. Diffuse and smooth on

II $\mathrm{B}_{2}$ 90-120 cm Reddish-yellow (7.5YR 6/5: dry) to intense brown (7.5YR 5/5: moist) gravelly silt loam with a moderately developed, medium subangular-blocky structure. Friable. Few roots. Porous. Gradual and smooth on

II $B_{3} 120-130 \mathrm{~cm}$ Light yellowish-brown (10YR 6/4: dry) to yellowish-brown (10YR $5 / 4:$ moist) calcareous, gravelly silt loam with a moderately developed, fine subangularblocky structure. Friable. Very few roots. Porous. Abrupt and wavy on

II C $+130 \mathrm{~cm}$ Very pale brown (10YR 8/3: dry and moist) weakly weathered porous limestone.

The whole profile shows a high biological activity.

Prof. XIX. Schrondweiler-Diekirch (Luxemburg) see also: VERHOEVEN, 1963). Rolling land. Gentle slope. Moderately well-drained. Parent material: Steinmergelheuper (Trias). Mean annual temperature $9^{\circ} \mathrm{C}$. Mean annual rainfall $750-850 \mathrm{~mm}$. Vegetation: permanent grassland.

$A_{1} \quad 0-8 \mathrm{~cm}$ Grey (10YR 5/1: dry) to very dark grey (10YR 3/1: moist) silty clay with a weakly developed, thick-platy structure. Porous. Firm. Cracks up to $2 \mathrm{~cm}$ wide. Some carbonate. Some fragments. Well-rooted. Diffuse and smooth on

$\mathrm{B}_{1} 8-25 \mathrm{~cm}$ Light brownish-grey (2.5YR 6/2: dry) to greyish-brown (2.5Y 4\%/2: moist) silty clay with a compound, well-developed, medium-prismatic and mediumblocky structure. Colour inside the prisms brown (10YR 4/3). Very firm. Cracks $(1-2 \mathrm{~cm}$ wide) up to $20 \mathrm{~cm}$ depth. Thick continuous coatings. Slickensides. Some manganese concretions. Few roots. Some carbonates along cracks. More fragments than in $A_{1}$. Diffuse and smooth on 
$B_{2} \quad 25-50 \mathrm{~cm}$ Pale olive (5Y 6/3: dry) to olive-brown (2.5Y 4/4: moist) channery clay with a compound, well-developed, coarse-prismatic and coarse-blocky structure. Colour inside the aggregates brown (10YR 4/3). Thick continuous coatings. Some slickensides. No cracks. Very few roots. Clear and wavy to irregular on

B $_{3} \quad 50-85 \mathrm{~cm}$ Pale olive (5Y 6/3: dry) to olive (5Y 4/3: moist) channery clay with a thick(or C) platy structure (consequence of the layered parent rock). Colour inside aggregates brown (10YR 4/3). Continuous clay skins. Some slickensides. Highly calcareous. No roots.

Prof. XX. Champex-Orsières (Switzerland). Mountainous land. Rather steep slope. Perfect drainage. Parent material: mixture of igneous and metamorphic rocks, containing amongst others: lime phyllite, granite, chlorite schist, mica schist, quartz, limestone. Mean annual temperature $5^{\circ} \mathrm{C}$. Mean annual rainfall $910 \mathrm{~mm}$. Altitude $1200 \mathrm{~mm}$. Vegetation: spruce.

$A_{1} \quad 0-22 \mathrm{~cm}$ Pale brown (10YR 6/3: dry) to dark greyish-brown (10YR 4/2: moist) gravelly and channery, sandy loam with a well-developed, fine-granular structure. Friable. Porous. Abundantly rooted. Gradual and smooth on

A $22-70 \mathrm{~cm}$ Very pale brown (10YR 61/2/3: dry) to brown (10YR 4/3: moist) gravelly and channery sandy loam with a moderately developed, fine subangular-blocky structure. Friable. Well rooted. Gradual and smooth on

B $70-80 \mathrm{~cm}$ Pink (7.5YR 7/5: dry) to brown (7.5YR 4/4: moist) gravelly and channery sandy loam with moderately developed, subangular-blocky structure. Porous. Few roots. Gradual and smooth on

$B_{2} \quad 80-95 \mathrm{~cm}$ Yellow (7.5YR 6/6: dry) to reddish-brown (5YR 4/4: moist) gravelly and channery sandy loam with a weakly developed, fine-blocky structure. Friable. Lower porosity than in $B_{1}$ and $A$. Some weakly developed discontinuous clay skins. Very few roots. Clear and smooth on

C $\quad+95 \mathrm{~cm}$ Very pale brown (10YR 7/4) to yellowish-brown (10YR 5/4) gravelly and channery sandy loam. Loose. No roots. 